first has to do with what the late Don McKenzie referred to as the "expressiveness of the artifact": These concentric wheels are intensely evocative of their contexts. Whether those contexts be World War Two or America's ongoing obsession with diets and health regimes, these calculating wheels can provide scholars with quirky and revealing ways into sociocultural milieus. Among other things, they "empower" users (to resurrect a term) in moments of challenge as well as in moments of play. Primary source material of this ilk may not, in itself, sustain a monograph, but it is capable of adding nuance and emphases in unexpected ways.

The second reason to take these artifacts seriously is a bit more abstract, but no less compelling, at least for this reviewer. Helfand is a designer, and her book seems to be aimed primarily at members of her own tribe. Her message to them has to do with the new opportunities for design applications based on circularity and "kinetic thinking" rather than on static grids and squares. Her collection is thus a working library for her and perhaps her gift to colleagues. But this doesn't mean that there is nothing here for us.

Wheel charts may be one of the earliest and most persistent types of interactive information media. It is the array of interactive possibilities latent in superimposed circles that interests Helfand and should interest us. From the standpoint of the history of books and reading, volvelles and their more recent progeny present historians with alternative examples of "reading" and learning. When Helfand talks about the "merits of kinetic thinking," she may not have the authority of the academy behind her, but she does suggest a potentially rich approach to interactive media that deserves further exploration.

Even if the reader is unimpressed by this reviewer's enthusiasms, she or he should still make a point of looking at this book. If nothing else, the remarkable display of twentieth-century wheel charts provides a rich and fascinating tour of an underappreciated genre of printed matter.-Michael Ryan, University of Pennsylvania.

\section{Scholarly Publishing: Books, Journals, Publishers, and Libraries in the Twen- tieth Century. Ed. Richard E. Abel, Lyman W. Newlin, Katina Strauch, and Bruce Strauch. New York: Wiley, 2002. 318p. alk. paper \$29.95, (ISBN 0471219290). LC 2001-6154.}

This publication provides a unique view into the world of scholarly publishing. Despite the large number of books now coming out in the field of publishing history and the flood of books critical of the current state of education, there are no works that treat so thoroughly the history, current situation, and future prospects of scholarly publishing. In addition to articles by librarians at the front lines of change, there are vibrant essays by some of the prime movers in publishing, bookselling, and library technology. Formats and topics as diverse as books and journals, microforms, CD roms, scholarly reprints, print on demand, e-books, and i-books are discussed both historically and in the current context.

The variety of perspectives provided by this amalgam of publishers, librarians, authors, booksellers, and journal dealers reflects the book's genesis at the Charleston Conference and in its journal Against the Grain. The Charleston Conference is already in its twenty-second year of bringing together all of the disparate elements in the scholarly publishing equation. It is a venue where librarians can confront publishers about pricing, where publishers can respond with questions about the "Napstering" of information, where copyright issues can be debated, where predictions about the future of libraries and publishing can be proposed and debated. In sum, it is a forum where all parties interested in scholarly publishing and the library market can meet face to face.

The two lead editors, Richard Abel, a seminal figure in scholarly bookselling, and Lyman Newlin, a veteran bookman with more than sixty years' experience in 
publishing and bookselling, were called on by Katina Strauch, founder of the Charleston Conference and editor of Against the Grain, to gather a fair cross section of these voices and produce a "Millennial" volume assessing the past century, especially the past fifty years, of scholarly publishing. The sixteen writers who were chosen then were asked to speculate about the future of publishing from their individual perspectives. The editors exceeded expectations by producing a volume that literally stands alone as a study of the field of scholarly publishing in its many forms.

The authors are all very straightforward in relating the early history of scholarly publishing and all agree that there was an explosion of scholarship and publishing in the first half of the century. They also agree that there has been a crisis in libraries and publishing since the 1970s. Where once there had been nearly bottomless funding for libraries and research, there now came the end of the Baby Boom, government blank checks, and constant expansion of university library budgets. To compound the situation, there also has been an explosion of scientific and technical research and publishing that is overwhelming these same libraries and their diminished budgets. As Albert Henderson, former editor of Publishing Research Quarterly, points out: "an assault on the latest Standards for College Libraries prepared by the Association of College and Research Libraries (C\&RL News 2000) . . . . excised the following passage:

‘[8.1] The library's annual authorized expenditures shall be at least six percent of the total institutional expenditure for educational and general purposes.'" Removing this criterion goes against long-standing recommendations. In addition to fostering subscription cancellation, it encourages the inadequate pay of librarians, as well as the impoverishment of other acquisitions, facilities, training, and services.
Peter Givler, executive director of the Association of American University Presses, gives a detailed history of university press publishing followed by a cogent analysis of the current economics and rationale of university press publishing. To quote Mr. Givler, "The year 1970 . .. marked the beginning of a slow decline in purchases by libraries of scholarly monographs, particularly in the humanities and social sciences, a decline that continues to this day and that has had a profound impact on university presses." But he concludes on a positive note, "the twenty-first century brings with it the opportunity for new relationships and new forms of collaboration between university presses, university libraries, and universities themselves."

This situation is amply explored by Michael Gorman, dean of library services, California State University-Fresno, in his essay "The Economic Crisis in Libraries: Causes and Effects." With the advent of a new "crisis" in library funding in our new millennium, Gorman's essay is a renewed call to arms to defend libraries and the inherited wisdom they embody.

Another pointed commentary can be found in the essay by Robert Follett simply titled "Textbook Publishing." Mr. Follett, who has been in the textbook and campus bookstore business for nearly fifty years, levels a challenge to all of those involved in writing and selecting textbooks to improve their work for the sake of readers and students. To quote Mr. Follett, "The best kind of publishing involves a close and intimate relationship between the author and the reader, with the publisher providing the essential bridge between them. This is not the case in most textbook publishing. That this is so is unfortunate for authors, publishers, educators, and most of all, students." His survey of the field and his understanding of the economics and social dynamics of textbook publishing make up another surprising perspective provided by this volume.

Stephanie Oda, editor and publisher of Subtext and president of Open Book Publishing, gives a detailed reading of the fi- 
nancial and social dynamics of bookstores and book distribution. As a market analyst, she provides the reader with information usually reserved for those inside the industry.

Ralph Shoffner, president of Ringgold Management Systems, offers a masterful history of library automation and electronic information sources. He speaks with the authority of one who has been intimately involved in the development of many of those systems. Accompanying his definitive history, Shoffner's "webography" is a valuable addition to the volume.

Essays by Jack Goellner, former director of the Johns Hopkins University Press, and Hendrilk Edelman, former director of the Rutgers School of Information and Library Science, provide even more historical perspective and a look into a future where, in the words of Professor Edelman, for research libraries "in another fifty years, most of these (paper) collections will become special collections with extensive preservation needs and, undoubtedly, much more limited access. It will be a considerable managerial, technological and architectural challenge."

Allen Veaner, former director of the University of Arizona Library, reflects on the kaleidoscopic array of information formats that libraries must deal with in his essay, "From Bibliotheque to Omnitheque." He, too, speculates about the difficulty libraries will have in preserving the myriad formats and technologies under their care.

Finally, Chuck Hamaker, associate university librarian for collections and technical services at UNC Charlotte, was given the task of speculating on the future of the traditional library in his essay, "The Place of Scholarly and Scientific Libraries in an Increasingly and More Widespread Competitive Information Knowledge Marketplace." Mr. Hamaker applies the scholarly rigor and appropriate statistics that he has continually brought to the argument to state as forcefully as possible that libraries and scholarly publishing, confronted with spiraling costs, cannot continue with the present contradictory models of poor funding and unlimited access to information. There are too many other points of access to high-quality information, especially on the Web, for libraries to continue trying to be all things to all users and for publishers to try to continue monopolizing scholarly communication.John Riley, Eastern Book Company and Gabriel Books 